\title{
The amazing growth of the early church
}

Author:
Wim A. Dreyer ${ }^{1}$
Affiliation:
'Department of Church
History and Church Polity,
University of Pretoria,
South Africa
Correspondence to:
Wim Dreyer
Email:
wim.dreyer@up.ac.za
Postal address:
17 Elephant Street,
Monument Park, Pretoria
0181, South Africa
Dates:
Received: 29 May 2012
Accepted: 26 July 2012
Published: 02 Nov. 2012
How to cite this article:
Dreyer, W.A., 2012, 'The
amazing growth of the early
church', HTS Teologiese
Studies/Theological Studies
$68(1)$, Art. \#1268, 7 pages.
http://dx.doi.org/10.4102/
hts.v68i1.1268

C 2012. The Authors. Licensee: AOSIS OpenJournals. This work is licensed under the Creative Commons Attribution License.
The church grew rapidly during the first centuries. The question is: Why? Generations of scholars approached this question from different perspectives and with different methods. Historical research, analysis of early Christian texts and theological reflection were the most common methods used to shed light on the growth of the church. In this contribution five different models of growth were discussed, using the approach of A.M. Schor as a point of departure. These models of church growth were put under the headings of an apostolic mission model, values reproduction model, social reaction model, network model with an institutional model added.

\section{Introduction}

Kennet S. Latourette (1964) wrote:

One of the most amazing and significant facts of history is that within five centuries of its birth Christianity won the professed allegiance of the overwhelming majority of the population of the Roman Empire and even the support of the Roman state ... The complete story of the spread of Christianity in its first five centuries cannot be told, for we do not possess sufficient data to write it. (p. 65)

Due to a lack of information, it is impossible to calculate accurately the growth of the Christian church during the first centuries. However, we know that within five centuries Christianity became the dominant religion of the Roman Empire. The Jesus-movement, which started in an obscure part of the Roman Empire, in a relatively short period transformed into a major religion with millions of followers spread out from India in the east, Ethiopia in the south to Britain in the west.

Although many questions will remain unanswered, the amazing growth of the early church is an enigmatic and important topic of research. What makes it even more relevant is the fact that Western churches experienced a major reduction in membership during the 20th century. Coupled to this is a growing and sharp criticism of the prosperity-driven, 'bigger is better' and institutionalised forms of the church (i.e. Viola \& Barna 2008). Radical questions are being asked of the church, often with the early church as an idealised point of reference.

So how did the Mediterranean world become predominantly Christian? Since Von Harnack's (18511930) church historical research, many scholars with different aims and methods, attempted to quantify and explain the growth of the early church - but each theoretical angle seems to reopen new questions (Schor 2009:472).

During the last decade or so, sociological methods of research became more prominent and resulted in much scholarly debate (see summary in Schor 2009:472-473). Most influential were the publications of Rodney Stark, professor of Social Sciences at Baylor University and author of several books on the subject (i.e. Stark 1996, 2006, 2007).

Stark describes the early church as an open but organised movement, with certain social boundaries and a kernel of doctrine. According to Stark, this character of early Christianity, coupled with a high birth rate, resulted in an exponential growth during the first three centuries (Stark 1996:4-45). Based on sociological methodology and analysis, Stark proposes that by 350 $\mathrm{AD}$ the majority of people within the boundaries of the Roman Empire were Christians (Stark 2007:313). These conclusions greatly influenced the development of missional ecclesiology and practice as developed by somebody like A. Hirsch (2006:18).

On the other hand, many were mildly to extremely critical of these attempts to quantify the growth during the first four centuries. Most critical are those who question Stark's disregard for the number of converts which are mentioned in the New Testament, that is, Acts 2:41. Others question his method of social analysis and quantification. Wilson (1997) formulates it as follows: 
I should point out that Stark's theoretical framework of cost-benefit analysis is hardly universally accepted among sociologists of religion. Is it true that religious affiliation can be explained by the economic model of rational choice in the religious marketplace? Is self-interest, even for spiritual rewards, sufficient to explain the motivation of religious commitment? Such criticism of Stark's theoretical foundations has been joined by many... (p. 131)

In this contribution the more recent work of A.M. Schor (2009) is utilised as a framework to reflect on the growth of the early church. Schor presents us with different quantitative models, each leading to different results. He does not attempt to give a final answer to the quantitative growth of the early church, but develops the different models as 'thought experiments' (Schor 2009:474). In fact, Schor makes it clear that each model has certain shortcomings. As such this contribution will not analyse the merits of his quantitative method and results, but rather focus on the integration of textual information within his framework.

Schor develops four models, to which this contribution adds a fifth, that is, an institutional model of growth.

\section{Apostolic mission model}

The first model Schor proposes is called the 'apostolic mission model' (2009:474). This model departs from the universal assumption that no conversion to any religion is possible without a process of convincing. Christians in the early church, at some or other stage in their lives, were convinced by someone they trusted to become Christians. The prime source of new Christian converts was the influence of individuals perceived to possess some spiritual gift (Schor 2009:475) like visionaries, martyrs, prophets, healers or learned men.

The importance the early church attached to mission is manifest in the New Testament. Jesus sends out His disciples (Mt 10; 28; Lk 10) and in Acts the missionary activities of the apostles, especially Peter and Paul, are described in some detail.

This missionary zeal of the Christians continued during the early development of the church. Eusebius of Caesarea describes in Book III/I of his Historia Ecclesiastica the geographical areas in which the apostles preached the Gospel (Schaff \& Wace 1961:132).

The Didache, probably dating back to the early 2nd century, mentions travelling teachers (see Didache XI in Goold \& Lake 1975:324-325). The first readers of the Didache are instructed 'if his teaching be for the increase of righteousness and the knowledge of the Lord, receive him as the Lord'. However, there were true and false teachers; the criterion to distinguish between them were their behaviour and example: 'From his behaviour then, the true and the false prophet will be known ...' (Goold \& Lake 1975:327).

From these passages it becomes clear that there were already established churches with some form of clergy, as well as travelling teachers who were received with hospitality and respect. These 'charismatic' teachers had to earn the trust of God's people by (1) their teaching which had to be in line with the accepted norm (orthodoxy) and (2) a lifestyle of humility and love (orthopraxis). They were regarded with respect, due to the fact that travelling implied hardship, danger and even death.

The apostle Paul's letters to the early church clearly shows that his authority as an apostle and teacher was not only based on his calling by Christ, but also confirmed by his suffering ( 2 Cor 11:16-33). Travelling teachers were not expected to stay too long in one place and abuse the local hospitality. Paul did not abuse hospitality but worked to sustain himself (1 Cor 4:12; Phlp 4). The travelling teachers, who followed this example and risked life and limb had a certain credibility and were important in spreading the Gospel.

During the first centuries the travelling healer (in contrast to the 'professional' physician in service of a patron) was a well-known figure (see Bazzana 2009). In the Christian context, these travelling healers were also missionaries. They were important in the missionary expansion of the church, especially in light of Schor's remark on 'spiritually gifted' individuals and the role they played in convincing people of the Gospel of Jesus Christ (Schor 2009:475).

With reference to the related passages in Matthew 10 and Luke 10 (the sending out of the disciples to heal and to preach), Bazzana points out that it was general practice in the GrecoRoman world for folk healers to travel from place to place. The modus operandi of Christians who were travelling healers, might be easily compared to patterns of medical activity widespread throughout the ancient Greco-Roman world (Bazzana 2009:235)

The healers of the early church had a role model in Jesus of Nazareth. For instance, Jesus is presented in the Gospel of Mark not only as a teacher, but also as a healer. In the Mediterranean context of the early church, teaching and healing roles were often connected. Healing was judged successful as long as it was capable of relating the patient's experience of disease to a culturally meaningful context (Bazzana 2009:247; see also Pilch 2000).

How highly the teacher or healer was regarded in the early church, is also seen in the 6th Nag Hammadi Codex. A recurring feature in these writings (as in many other ancient texts) is a polemical attack against the institutionalised medical practice. A clear instance appears in the so-called Acts of Peter and the Twelve Apostles, a composite work that figures at the beginning of the Codex (Bazzana 2009:240). According to the Acts of Peter, Jesus sends out the Twelve to heal the sick:

He (Jesus) gave them the pouch of medicine and said, 'Heal all the sick of the city who believe in my name.' Peter was afraid to reply to him for the second time. He signalled to the one who was beside him, who was John: 'You talk this time.' John answered and said, 'Lord, before you we are afraid to say many 
words. But it is you who asks us to practice this skill. We have not been taught to be physicians. How then will we know how to heal bodies as you have told us?' He answered them, 'Rightly have you spoken, John, for I know that the physicians of this world heal what belongs to the world. The physicians of souls, however, heal the heart. Heal the bodies first, therefore, so that through the real powers of healing for their bodies, without medicine of the world, they may believe in you, that you have power to heal the illnesses of the heart also. The rich men of the city, however, those who did not see fit even to acknowledge me, but who revelled in their wealth and pride - with such as these, therefore, do not dine in their houses nor be friends with them, lest their partiality influence you. For many in the churches have shown partiality to the rich, because they also are sinful, and they give occasion for others to sin. But judge them with uprightness, so that your ministry may be glorified, and that my name also, may be glorified in the churches.' The disciples answered and said, 'Yes, truly this is what is fitting to do.' (Bazzana 2009:241)

Another facet of apostolic missionary activity that did not include travelling, preaching and healing, was writing. The letters of the apostles (like Paul) were important in spreading the Gospel and defending the Christian faith against Jewish influences, heretics and pagan religion. In this tradition the Apologists continued - defending, explaining, interpreting and spreading the Gospel. These 'people with authority' were also bishops, presbyters and deacons (Schor 2009:475).

Both 'institutional' clergy and 'charismatic' teachers were involved in the conversion of people. As the process of institutionalisation continued (Dreyer 2011:47-65), the bishops progressively subordinated the charismatic leaders (Schor 2009:475), but they continued to play an important role in conversions.

What would the effect of these apostolic and missional activities be? How did it translate into conversion and the growth of the early church?

To make a calculation of church growth based on the apostolic mission model, Schor takes certain factors into consideration that is, the geographical spread of bishops according to early sources; the assumption that charismatic teachers and healers continued to play a certain role in conversions; assuming that a cleric would convert 10-15 people per year and a charismatic teacher or healer 25 people and by extrapolating these numbers statistically Schor reaches the conclusion that by the year $350 \mathrm{AD}$ there could have been as many as 15.8 million Christians within the Roman Empire (Schor 2009:477).

\section{Values reproduction model}

Since the very beginning, starting with Jesus, Christianity transmitted certain social values (Schor 2009:478). Values like charity, mutual support, self-control and others drew people to Christianity (Schor 2009:478). It was not only the teaching of these values by the clerics which attracted people, but rather the way ordinary Christians gave practical and physical expression to Christian love. We find this reflected in many different texts, of which a few examples will be given:
The First Letter of Clement to the Corinthians (1st Clement) is a very early document, dating between 75 and $110 \mathrm{AD}$, probably not later than 100 AD (Goold \& Lake 1975:5). In 1st Clement XXXVIII the question of mutual assistance and care is addressed. There we read:

Let the strong care for the weak, and let the weak reverence the strong. Let the rich man bestow help on the poor and let the poor give thanks to God, that He gave him one to supply in his needs; let the wise manifest his wisdom not in words but in good deeds ... (Goold \& Lake 1975:72)

Eusebius writes in 324 AD in his Historia Ecclesiastica (Book IX/VIII) about the great famine and pestilence ( $\alpha v \theta \rho \alpha \xi)$ which broke out in Armenia during the reign of Maximinus. Maximinus Thrax was emperor from 235-238 AD. Eusebius describes in considerable detail how people were dying in the streets of hunger and pestilence, so much so that the dogs started feeding on the dead bodies. Eusebius writes:

In this way death, waging war with these two weapons, pestilence and famine, destroyed whole families in a short time, so that one could see two or three dead bodies carried out at once ... Then did the evidences of the universal zeal and piety of the Christians became manifest to all the heathen. For they alone in the midst of such ills showed their sympathy and humanity by their deeds. Every day some (Christians) continued caring for and burying the dead, for there were multitudes that had no one to care for them; others collected in one place those who were afflicted by the famine throughout the whole city, and gave bread to them all; so that this thing became noised (spoken of) abroad among all men, and they glorified the God of the Christians and, convinced by the facts themselves, confessed that they alone were truly pious and religious ... (Schaff \& Wace 1961:362-363)

Schor (2009:478) refers to Pachomius who was drawn to the church by the Christians' charitable giving, mutual support and self-control which he observed. Crucially, it was not clerics whom he observed, but ordinary Christians, living out their teachings. These values helped to define Christian communities; it gave them a certain identity with which people could associate.

One of the values which were important to early Christians, was the sanctity of life. This had a direct impact on their reproduction (birth) rate. Early Christians did not take part in infanticide, abortion or the selling of children into slavery. It was not an uncommon practice during the time to leave unwanted children outside to be eaten by wild animals. It reminds one of the children's story of Hansel and Gretel.

An interesting expression of these values can be found in the Epistle to Diognetos. The Epistle to Diognetos is of uncertain date, but should be regarded as part of the corpus of early Apologists (Goold \& Lake 1975:348). In Diognetos V (Goold \& Lake 1975) we find a gripping depiction of the distinction between Christians and non-Christians:

For the distinction between Christians and other men, is neither in country or language nor customs ... They dwell in their own fatherlands, but as if sojourners in them; they share all things as citizens, and suffer all things as strangers. Every foreign country is their fatherland, and every fatherland is a foreign country. They marry as all men, they bear children, but they do 
not expose their offspring. They offer free hospitality, but guard their purity ... (pp. 358-361)

By explaining this strange lifestyle and behaviour of Christians in such a dialectical manner, the Epistle to Diognetos intends to defend, explain and interpret the Christian faith and values - at the same time trying to convince and convert.

Schor (2009:481), with reference to Stark (1996:4), concludes that these values contributed to a higher birth rate under Christians than the general population, resulting in accelerated growth. Again, using quantitative models based on certain assumptions, Schor concludes that this model of growth indicates that the number of Christians could have reached 33.9 million by $350 \mathrm{AD}$ (Schor 2009:481). He explains it as follows:

[This] model projects a tiny Christian community for the first few generations. This seems to make sense of the invisibility of Christians in early imperial sources. At the same time, it projects rapidly increasing numbers in later generations. Christian growth might look miraculous. But to Stark, it was a matter of 'arithmetic.' And yet, an exponential model does not tell us when the 'explosion' of Christian growth took place. Again, much depends on initial numbers and the supposed rate of growth ... For example 1, assume there were 1000 Christians in $40 \mathrm{CE}$ (as Stark does). Assume a slightly positive of Christian reproductive growth (5\% per decade) and a rapid rate of growth via conversion (say, $35 \%$ per decade), for a total of $40 \%$ (also Stark's suggestion). Our formula would then produce Stark's numbers ... (Schor 2009:481)

The calculation of Stark to which Schor refers, suggests that the number of Christians grew to approximately 20 million by $310 \mathrm{AD}$ and possibly as high as 33 million by the year 350 AD (Stark 1996:6-13; Hirsch 2006:18; Schor 2009:481).

\section{Social reaction model}

Conversion to Christianity was never just about theology or behavioural norms; it was about group relations. 'Christian praxis demarcated the church as an imagined community, linking unacquainted people across hundreds of cities' (Schor 2009:483). Ordinary social contact between Christians and non-Christians would have greatly influenced people to convert. Stark explains that people tend to convert when their social relations tilt more towards the new community than the older (Schor 2009:483; Stark 1996:16).

It is not clear from which social and economic strata the early Christians came (Latourette 1964:80). At first, Christianity was primarily an urban religion. Theories abound that early Christianity drew its first converts from the dregs of urban society, i.e. slaves, labourers, outcasts and dispossessed people. Early Christians were not afraid to associate with those on the fringes of society. Christian masters freed their slaves who converted to Christianity. The official emancipation took place in the presence of the bishop. Several of these freed slaves eventually became bishops themselves (Chadwick [1967] 1986:60).

At the same time, there is also a clear indication that many wealthy, important merchants and members of the nobility converted to Christianity. For instance, Tacitus (60-120 AD) writes in his Annales (ch. xiii) about the trial of Pomponia Graecina, 'a woman of high rank', the wife of Aulus Plautius who conquered the southern part of Britain (43-47 AD). During the year 57 AD he gave his wife over to trial, following ancient precedent in hearing his wife's case in the presence of family. He pronounced her innocent (see Bettenson 1943:1). It is possible that some of the most prominent Roman families converted at an early stage to Christianity, influencing many others around them. For instance, it is known that Emperor Domitian had relatives (his nephew, the consul T. Flavius and his wife Flavia Domitilla) executed who were known to be Christians and in line to become emperor (Latourette 1964:80; Bakhuizen van den Brink 1965:69).

Many women became the first converts in a family (Chadwick [1967] 1986:58), often leading their husbands to conversion but even more so raising their children as Christians. It was often through wives that Christianity penetrated the upper classes of Roman society, with the result that Christians became increasingly influential. One of the most famous mothers of the early church was Monica, whose son Augustine is regarded as the most important theologian of all times.

Schor (2009) indicates which factors relating to social interaction would influence people to convert:

Beyond particular social pressures, interacting individuals were also affected by the political and cultural environment. Contacts might be quickened by sympathetic leaders, by increased trade and travel, or by pre-existing sites of interaction (such as synagogues). Contacts might be weakened by prejudicial attitudes, regional isolation, gender separation, distinctions of social rank, or the threat of persecution (though martyrdoms probably did raise the Christian profile). For someone already interacting with Christians, conversion catalysts might include theological similarities, shared values, or understandable rituals. (p. 484)

After 313 AD, when Constantine promulgated the Edict of Milan, Christianity grew even faster. It became socially acceptable to be a Christian, as it had certain privileges - for example, clergy were exempted from tax - and could ensure association with the leaders and elite of certain communities (Latourette 1964:92). This led to a quick growth in clergy.

It is clear that Christianity became an important social factor. The church grew from a small minority to an influential majority. As society tilted more and more toward Christianity, social interaction and relatedness ensured a rapid increase in conversions.

Based on the social reaction model, Schor's calculations indicate that the number of Christians reached approximately 20.2 million by $350 \mathrm{AD}$.

\section{Network model}

An important new development is the network theory based on mathematical analysis of relational systems. Schor (2009) explains it as follows: 
The new approach to modelling is a product of network theory, a branch of mathematics devoted to analysing relational systems. Here, a network is any system that can be represented as a set of 'links' connecting a series of 'nodes.' Since the 1960s, the basics of network theory have found a place in anthropology and historical research. 'Social' network theory treats society as a web of overlapping relationships, with friendships, patronage connections, and alliances as the links and people as the nodes. (p. 493)

According to Manuel Castells (2000:164) networks are made up of lines of communication that connect a series of nodes or hubs. The nodes represent individuals, organisations or communication systems. This means that information and decision-making are not localised, but reside in a 'process' (Ward 2002:42). This is not only true of current society dominated by communication networks, but of all societies. There have always been lines of communication connecting individuals and groups together. This results in a 'liquid' society (Bauman 2000; Ward 2002). Ward contends that the church of the future will be much less institutionalised and hierarchical, functioning as open, liquid communication networks.

According to Schor (2009:494), social network theory has been fruitfully applied to the dynamics of contained groups or the place of individuals in society. Network theory aided Stark's research including the groundbreaking conclusion that almost all converts to modern religious groups have friendships or familial bonds with existing members. Schor (2009) explains the importance of this approach as follows:

Network theory thus allows for a more nuanced model of the Christian community. But how can this help us to understand conversion? While network models cannot give a precise count of Christians, they can offer new insights into the dynamics of Christian growth. These suggestions come from the field of network science. Over the last two decades, scholars have investigated many kinds of 'self-organizing' networks, from biological ecosystems, to economic systems, to the World Wide Web. Across fields, they have found consistent patterns in the way networks form, grow, change, and collapse. Because of this consistency, one can hypothesise about how the Christian community organised itself, subdivided, and found so many adherents. (p. 495)

The different network models help us to understand how the early church functioned and had the ability to preach the Gospel over vast areas. As already indicated, travelling teachers, healers and merchants were important in the dissemination of Christian beliefs (see Arterbury 2005). In villages, towns and cities groups of Christians gathered, receiving travelling teachers with hospitality. These travellers brought news, maybe money to assist the local Christians and to carry news and contributions to the next group of Christians.

Where there were no Christian communities, these teachers and healers would stay and establish a small group of Christians.

According to Chadwick ([1967] 1986:54), the pagan writer Celsus (c. 180 AD) described the close-knit structure and coherence of the Christians as a social group. He wrote: 'Their agreement is quite amazing ...' The way the early Christians were interconnected and communicated via travelling teachers, healers and letters is very much a communication network which functioned on an informal basis, but with time on a more formal basis. The bishop and Christian congregation in a certain area would function as a 'node', a point of reference and support, sending out and assisting teachers to travel further. It meant that even very small groups of Christians could be reached.

\section{Institutional model of church growth}

The institutionalisation of the church, especially after the Edict of Milan (313 AD), is currently regarded as a very negative development in the history of the church. For many, it constituted a significant departure from what the church as body of Christ was meant to be. However, departing from Schor's models, I would suggest that the institutionalisation of the early church significantly contributed to the rapid growth of the church.

The calculations discussed previously, indicated a jump in growth in the period 313-350 AD. This had much to do with the fact that the church had become a powerful institution with resources. With the support from the emperor, the church was more and more in a position to assist people with their daily needs giving protection and intervene on their behalf in legal matters.

During the 20th century, the institutionalism of the church had been severely criticised. Alfred Loisy (1857-1940), the Roman Catholic priest and professor of theology who was excommunicated by the pope, is remembered for his famous observation Jésus annonçait le Royaume et c'est l'Église qui est venue. Loisy did think that Jesus intended to form some sort of community, but it was the aping of civil government (comme celle d'un gouvernement établi) Jesus did not intend (Loisy 1902:152). This line of thought was continued by G.J. Heering, who described the transformation of the Jesusmovement into an institutionalised church as the fall of Christianity (Heering 1928).

At the beginning of the 21st century, these sentiments are echoed by prominent exponents of missional ecclesiology like Hirsch (2006), Viola and Barna (2008) and Ward (2002). The general consensus is that institutionalisation is bad for the church, especially in a post-Christendom and postmodernist era.

This might be true in the 21st century, but during the 4 th century the protection of the state and the development of the corpus christianum had a marked effect on the church. We read in the Edict of Milan:

When we, Constantine and Licinius, Emperors, met in Milan in conference concerning the welfare and security of the realm, we decided of the things that are of profit to all mankind, the 
worship of God ought rightly to be our first and chiefest care, and it was right that Christians and all others should have freedom to follow the kind of religion they favoured ... Moreover, concerning the Christians, we before gave orders with respect to the places set apart for their places of worship. It is now our pleasure that all who have bought such places should restore them to the Christians, without any demand for payment ... (see Bettenson 1943:22)

The restitution of church property, the development of new places of worship, the remuneration of clergy and tax exemption for clergy clearly had a beneficial effect on the early church.

Tertullian wrote in his Apologia (197 AD) to the Roman governor of his province, refuting charges being made against Christians and the Christian faith, arguing that the followers of Christ were loyal subjects of the empire, and thus should not be persecuted. He writes: 'Plures efficimur, quotiens metimur a vobis, semen est sanguis christianorum' (see Altaner 1951:126). This remark, that the blood of the martyrs is the seed of the church, became a standard answer to the question of why the church grew so fast.

In a sense this is true, as we saw above where the role of trusted leaders, preachers and healers was discussed. Martyrdom was convincing. But the opposite is also true: with freedom of religion granted by Constantine and Licinius, even more possibilities of growth opened up. Many, who feared persecution, now had the freedom to convert to Christianity.

The freedom of religion and to hold gatherings, as well as the restitution of church property, had the effect that spontaneous expressions of Christian love (like hospitality to the stranger, caring for the sick and feeding the hungry), became more and more the responsibility of the deacon and the official structures of the church. This made the church attractive: it was a place where you could receive care and comfort in times of tribulation. The institutionalised diaconate of the early church drew many of those suffering poverty and illness to the church.

To date, there has been no in-depth published study of the history of the institutionalised diaconate in either the Eastern or the Western churches beyond the early Middle Ages (Pokusa 1979; eds. Rahner \& Vorgrimler 1962; Kennedy 2011). There are at least fourteen hundred years for which our knowledge of the history of the diaconate is incomplete. In contrast to this lack of information, we find that the diaconate during and after the 16th century Reformation has been well documented and researched (i.e. Innes 1983).

Even with the limited knowledge of the formal diaconate, we know that as early as the 2nd century, during the pre-conciliar period, theological reflection on and implementation of the diaconate were already in an advanced stage (Kennedy 2011:1). In the early 2nd century, Ignatius (3rd bishop of Antioch, +110 AD) wrote a letter to the Trallians in which he said the following about the deacon: 'Likewise, let all respect the deacons as Jesus Christ ...' (Gould \& Lake 1975:214). The Christian diaconate found its roots in the teaching of Jesus Christ and the way that the proto-church in Jerusalem organised itself.

In the post-Constantine era, the diaconate had the freedom to develop and drew many to the church and to conversion. The same happened with the important issue of hospitality. According to Arterbury (2005:128), the majority of references to hospitality in the New Testament deal with the custom of private hospitality, but a dramatic shift in Christian hospitality can be detected at least by the 3rd century. Hospitality was placed under the authority of the bishop (cf. 1 Tm 3:1-7; Tt 1:5-9), and hospitality primarily became a charitable service for travellers collectively performed by entire congregations and supported with the corporate funds that were available to those congregations.

Cyprian (c. 200-258 AD) represents a major turn towards the institutionalisation of Christian hospitality and away from private hospitality. Rather than encourage individual Christians to host travellers, Cyprian taught that either the bishop should assist travellers on behalf of the congregation using the congregation's funds, or the bishop should at the very least determine when parishioners were allowed to extend hospitality to travellers (Arterbury 2005:128). After Constantine began to favour the Christians, bishops not only had more power, but they also had significantly more financial resources at their disposal, resources which could in turn be used to expand the custom of hospitality.

The questions remain: Was institutionalisation of the early church only bad, theologically and otherwise? Was it the fall of Christianity? Numerically the church grew as a result of the important role the institutionalised church played in the post-Constantine period. Even in the 21st century it is often clear that missionaries still need a 'home base'. In a network model of mission, there is still a nucleus which provides stability and continuity. The challenge to the 21st century church is probably to find a balance between the continuity and resources of the church as institution and the dynamic and missional character of non-institutional church.

\section{Conclusions}

Quantitative modelling has serious shortcomings and cannot present us with definite answers on the growth of the early church, due to many variables. These models cannot tell us exactly how many Christians there actually were, or why.

However, quantitative modelling can help to investigate the factors that scholars have suggested drove conversion. The majority of studies of early Christianity appropriately focus on textual interpretation. By using textual sources in combination with sociological and quantitative modelling, new lines of enquiry open up.

This not only leads to a better understanding of factors which facilitated the growth of early Christianity, but could also 
assist the church in understanding and implementing its missional calling in the 21st century.

\section{Acknowledgements Competing interests}

The author declares that he has no financial or personal relationship(s) which may have inappropriately influenced him in writing this article.

\section{References}

Altaner, B., 1951, Patrologie: Leben, Schriften und Lehre der Kirchenväter, Herder, Freiburg.

Arterbury, A.E., 2005, Entertaining angels: Early Christian hospitality in its Mediterranean setting, Phoenix Press, Sheffield.

Bakhuizen van den Brink, J.N., 1965, Handboek der Kerkgeschiedenis, Deel 1., Bert Bakker Daamen N.V., Den Haag.

Bauman, Z., 2000, Liquid Modernity, Polity Press, Cambridge.

Bazzana, G.B., 2009, 'Early Christian Missionaries as Physicians Healing and its Cultura Value in the Greco-Roman Context', Novum Testamentum 51, 232-251. http:// dx.doi.org/10.1163/156853609X407493

Bettenson, H. (ed.), 1943, Documents of the Christian Church, Oxford University Press, London.

Castells, M., 2000, The rise of the network society, 2nd edn., Blackwell Publishers, Oxford.

Chadwick, H., [1967] 1986, The early church, Pelican, Harmondsworth.

Connolly, R.H., 1929, Didascalia Apostolorum: The Syriac Version Translated and Accompanied by the Verona Latin Fragments, Clarendon Press, Oxford.

Dreyer, W.A., 2011, 'Praktiese Ekklesiologie en Bedieningspraktyk met besondere verwysing na die Nederduitsch Hervormde Kerk van Afrika', PhD verhandeling, Departement Praktiese Teologie, Universiteit van Pretoria.

Goold, G.P. \& Lake, K., 1975, The Apostolic Fathers vol. 1 \& 2, original texts ed. G.P. Goold and transl. K. Lake, Harvard University Press, Cambridge, MA.
Heering, G.J., 1928, De zondeval van het christendom, s.n. Utrecht.

Hirsch, A., 2006, The forgotten ways: Reactivating the missional church, Brazos, Grand Rapids.

Innes, W., 1983, Social concern in Calvin's Geneva, Pickwick Publications, Allison Park, PA.

Kennedy, D., 2011, 'Diaconate in the Ukrainian Catholic Church: An Outline of a Paradigm', viewed 22 April 2012, from http://diaconateinchrist.typepad.com/ diaconate-in-christ/2011/01/the-diaconate-in-the-ukrainian-catholic-church-anoutline-of-a-paradigm.html.

Latourette, K.S., 1964, A History of Christianity, Eyre \& Spottiswoode, London.

Loisy, A., 1902, L'Évangile et l'Église, Picard, Paris.

Pilch, J.J., 2000, Healing in the New Testament: Insights from Medical and Mediterranean Anthropology, Fortress, Minneapolis.

Pokusa, J.W., 1979, 'A Canonical-Historical Study of the Diaconate in the Western Church', doctoral dissertation, Department of Theology and Religious Studies, The Catholic University of America.

Rahner, K. \& Vorgrimler, H. (eds.), 1962, Diakonia in Christo, Herder, Freiburg.

Schaff, P. \& Wace, H., 1961, A select library of Nicene and Post-Nicene Fathers, W.M. Eerdmans Publishing Company, Grand Rapids.

Schor, A.M., 2009, 'Conversion by the Numbers: Benefits and Pitfalls of Quantitative Modelling in the Study of Early Christian Growth', Journal of Religious History 33(4), 472-498. http://dx.doi.org/10.1111/j.1467-9809.2009.00826.x

Stark, R., 1996, The Rise of Christianity: How the Obscure, Marginal Jesus Movement Became the Dominant Religious Force in the Western World in a Few Centuries, Harper Collins, San Francisco.

Stark, R., 2006, Cities of God: The Real Story of How Christianity Became an Urban Movement and conquered Rome, Harper, San Francisco.

Stark, R., 2007, Discovering God: The origins of great religions and the evolution of belief, Harper Collins, New York.

Viola, F. \& Barna, G., 2008, Pagan Christianity?: Exploring the roots of our church practises, Tyndale House Publishers Inc., Carol Stream, II.

Ward, P., 2002, Liquid Church, Hendrickson Publishers, Peabody.

Wilson, A., 1997, 'Book review of "The Rise of Christianity: A Sociologist Reconsiders History" by Rodney Stark', Journal of Unification Studies 1, 131-135, viewed 20 April 2012, from http://www.journals.uts.edu/volume-i-1997/45-book-reviewithe-rise-of-christianity-a-sociologist-reconsiders-historyi-by-rodney-starkprinceton-nj-princeton-university-press-1996.html. 